\title{
A study on the relationship between intellectual capital, earning per share and income growth: A case study of Tehran Stock Exchange
}

\author{
Ali Akbar Farzinfar ${ }^{*}$
}

Department of Accounting, Kashan Branch, Islamic Azad University, Kashan, Iran

\begin{tabular}{|c|c|}
\hline A R T I C L E I N F O & A B S T R A C T \\
\hline $\begin{array}{l}\text { Article history: } \\
\text { Received August } 25,2012 \\
\text { Received in revised format } \\
25 \text { September } 2012 \\
\text { Accepted } 4 \text { October } 2012 \\
\text { Available online } \\
\text { October } 72012\end{array}$ & $\begin{array}{l}\text { The primary aim of this survey is to study the relationship between intellectual capital, earning } \\
\text { per share and income growth for a case study of Tehran Stock Exchange in Iran. There are } 120 \\
\text { companies listed in Tehran Stock Exchange and, using a simple sampling technique, we choose } \\
50 \text { firms, randomly. The results of this survey indicate that the components of intellectual } \\
\text { capital including human capital, customer capital, and structural capital have significantly } \\
\text { positive relationship with the earning per share of the companies over the period of 2005- } 2010 \text {. }\end{array}$ \\
\hline $\begin{array}{l}\text { Keywords: } \\
\text { Intellectual capital } \\
\text { Tehran Stock Exchange }\end{array}$ & $\begin{array}{l}\text { The results also indicate that the components of intellectual capital including human capital, } \\
\text { customer capital, and structural capital are positively associated with the income growth of the } \\
\text { companies for the period from } 2005 \text { to } 2010 \text {. }\end{array}$ \\
\hline
\end{tabular}

(C) 2012 Growing Science Ltd. All rights reserved.

\section{Introduction}

There are different governmental managers who think that intellectual capital (IC) represent basic assets, which guarantee the success of business units. Intellectual assets can increase productivity and efficiency, which impact positively on the market. However, it is rarely observed IC on firms' balance sheets, which is in a serious conflict with knowledge economy where the basis of knowledge of established on (Boekestein, 2009). Therefore, firms are capable of reaching competitive advantage through keeping IC and we require to find out on how to assess IC and the impact of IC on other financial figures.

Azad and Mohajeri (2012) first calculated IC based on the ratio of market value/book value for three years period. Then they studied the relationship between IC and growth rate of IC as well as financial performance of some publicly traded petrochemical and pharmaceutical firms. The results of their survey indicated that there was a positive relationship between IC and equity growth with EVA and return of assets. However, there was no meaningful relationship between intellectual assets with net

* Corresponding author.

E-mail addresses: farzinfar_47@yahoo.com (A. A. Farzinfar) 
earning. A knowledge-based perspective is the main key for having successful organizations. However, it is also vital to use dynamic method on assessing intangible assets (IA) (Delgado-verde et al., 2011).

According to Martin (2008), successful firms keep strong human resources with good experiences and could add to firms through team-work activities. Intellectual properties are among knowledgebased items, which could contribute to business models, significantly. In other words, IA is an exclusive part of a business unit and this could normally incorporate different items such as good will, reputation, brand, etc. (Huggins, 2007; Boekestein, 2009). According to Isaac and Herremans (2009), IC is an exclusive intellectual property, which permits firms to have continuous improvement proportion to changes on the environment.

Manzari et al. (2012) presented a general review of IC literature, which incorporates definitions, components and indicators. They planned to gather a useful collection of indicators and definitions. After studying different related works from the literature, different definitions and indicators were determined and explained that choosing appropriate indicators depends on organizational targets. Every kind of organization can use this study to identify its more applicable and appropriate indicators to know about its IC. Identifying all of indicators in previous studies can help organization select right indicators for the organization. IC operates as the most important contributor to justify the value difference between market value and book value of many organizations (Beattie \& Thomson, 2007; Bozbura et al., 2007; Mouritsen et al., 2001; Wall et al., 2004; Yang \& Lin, 2009). Chen et al. (2004) provided a model in their study "Measuring Intellectual Capital: A New Model and Empirical Study" for the measurement of intellectual capital based on qualitative indices. The results of this research confirm a justifiable significant relation between intellectual capital and performance.

After the emergence of knowledge economy, knowledge is preferred more than other manufacturing factors such as land, capital, machineries, etc, in such a way that, in this economy, knowledge is regarded as the most important manufacturing factor and competitive advantage of organizations. If the most important wealth of an organization are the personnel, higher productivity therefore depends on the development their talents. In different firms and companies, what is known (intellectual capital) is more important than what is owned (financial assets), and the most competitive advantage of organizations is their ability to manage knowledge, which is regarded as the most essential capital, to which they have access.

The emergence of knowledge economy has also required new models of organizational assets. In general, organizational assets can be divided into two broad types:

1- Tangible assets: includes physical and financial assets, which are totally reflected in the balance sheets of companies. These assets are subject to the principles of economy of scarcity. This means that the increase in the use of such assets reduces their values.

2- Intangible assets: are classified into two general groups:

2-1- Intangible assets that are protected by law, and regarded as intellectual properties including all loyalties, copyrights, franchises, brands, trademarks, etc. some of these intangible assets are inserted in the balance sheet.

2-2- Other intangible assets including intellectual capitals that are subject to economic principles.

\section{Research Problem}

The increase in the gap between market value and book value of companies has encouraged researchers for several studies to recognize the items deleted from financial statements. The increase in market value exceeding book value of companies confirms that the market value of a company is not affected by the financial statements. The emergence of knowledge economy mainly based on 
knowledge and information has led the increase in paying attention to intellectual capital, which has attracted the attention of many scholars and experts of this field, and is used as a device to determine the value of a company.

Companies are required to focus on their competitive advantage to survive. As markets, products, technologies, competitors, and regulations of a society may change rapidly, the sustainable improvement of knowledge and innovations help them preserve their competitive advantages. Therefore, directors regard knowledge and the ability to produce and apply knowledge as the most sources of sustainable competitive advantages, since knowledge is considered as an asset, which has been managed and applied successfully for directing organizations.

One of the most important problems of traditional accounting systems is their inability to assess and measure intellectual capitals of companies, especially knowledge organizations. In the present knowledge - oriented societies, the return on intellectual capital has gained significance increasingly for profitability and financial returns in comparison to financial assets. Thus, a trend has been emerged recently for the measurement of actual value of intellectual capital as an intangible asset, and considerable measures has been taken to recognize, measure, and report such assets. Moreover, most companies, shareholders (investors), and other beneficiaries are interested to find proper answers for the following questions:

1- What is the appropriate method for the assessment of intellectual capitals of companies?

2- Is there any significant statistical relation between the intellectual capital of companies and their earning per share and income growth?

\subsection{Scope of Research}

This research aims to study the relation between intellectual capital and the earning per share, as well as income growth of companies. For this purpose, all companies of Tehran Stock Exchange are in the scope of this research. For the purpose of this research, the information of these companies for the period from 2005 to 2009 has been used.

\subsection{Operating Definitions}

Intellectual Capital: means the difference between market value and book value of a company; in other words, intellectual capital is the ownership of knowledge, applied experience, organizational technology, customer relations, and professional skills that provide an organization with competition ability in market. Intellectual capital is divided into three parts.

Pulik Method: means the method used in this research, upon which the value added intellectual coefficient is obtained by adding human capital to structural capital, and customer capital as follows:

$\mathrm{VAIC}_{\mathrm{i}}=\mathrm{CEE}_{\mathrm{i}}+\mathrm{HCE}_{\mathrm{i}}+\mathrm{SCE}_{\mathrm{i}}$

where,

VAICi: is the value added intellectual coefficient of the company $i$,

$\mathrm{CEE}_{\mathrm{i}}$ : is the customer employed efficiency coefficient of the company $i$,

$\mathrm{HCE}_{\mathrm{i}}$ : is the human capital efficiency coefficient of the company $i$,

$\mathrm{SCE}_{\mathrm{i}}$ : is the structural capital efficiency coefficient of the company $i$;

Pulik (1998) states, that the efficiency of value-added earned from the total sources of a company is in a better status, when VAIC is high.

Customer Capital Efficiency: is an index based on physical capital, which is a combination of the knowledge obtained from marketing channels, and customer relations of an organization. 
Human Capital Efficiency: is an index based on human capital, which is the stored knowledge of a member of an organization including the competencies and ideas of the personnel.

Structural Capital Efficiency: is an index based on structural capital that consists of non-human knowledge storages in an organization including databases, organizational charts, processes, and strategies providing the related organization with a value higher than its other materials.

Earning per Share: means the earning or profits of each share obtained by dividing the net profit of a company minus tax by the number of the shares owned by the shareholders at the time of preparing the balance sheet.

\section{The proposed study}

\subsection{Research Hypotheses}

This research uses Pulik model to study the following two hypotheses:

Hypothesis 1: There is a significant relation between intellectual capital and the earning per share ratio of a company.

Hypothesis 2: There is a significant relation between intellectual capital and income growth of a company.

\subsection{Research Method}

This research is an applied study in the field of accounting. To assess intellectual capital Pulik method is used, as in this method, the information of the financial statements of companies are used and inserted in the specified equation in order to calculate the intellectual capital and its components. The criteria of earning per share ratio and income growth of companies are obtained from the notes provided together with financial statements of the companies of the stock exchange. After summing up the information using Excel application, statistical analyses are carried out using SPSS and EVIEWS applications by multivariate regression and econometric models forming the descriptiveregression method based on panel data analysis.

To test the hypotheses of the research, regression and correlation analyses are used. The significance of the models is determined using determination coefficient, correlation coefficient, t-statistic, and Durbin - Watson test. For the purpose of this ex post facto research, a descriptive-inductive method is applied.

\subsection{Statistical Population}

The companies listed on Tehran Stock Exchange form the statistical population. To increase the comparability and reliability of the results of this research, 120 companies have been chosen from Tehran Stock Exchange based on the following criteria $(\mathrm{N}=120)$.

According to these criteria, the selected companies shall:

1) Not be a financial broker.

2) Be listed on the stock exchange before five years ago.

3) Have broad and complete information obtainable from their annual financial statements together with the market value of the shares at the end of the relevant fiscal year for the fiveyear period (from 2005 to 2010).

4) Finally, within the five-year period, the net profit of the companies shall not be equal to zero or a negative value after the deduction of tax.

\subsection{Statistical Sample}

After determining the statistical population of the research, it is required to find out the size of the sample, upon which the parameters of the population are inferred. Considering that the size of the 
population is limited, we could use the following formula to calculate the minimum number of sample size,

$n=\frac{N \times z_{\alpha / 2}^{2} \times p \times q}{\varepsilon^{2} \times(N-1)+z_{\alpha / 2}^{2} \times p \times q}$,

where $N$ is the population size, $p=1-q$ represents the yes/no categories, $z_{\alpha / 2}$ is CDF of normal distribution and finally $\varepsilon$ is the error term. Since we have $p=0.5, z_{\alpha / 2}=1.96$ and $N=120$, the number of sample size is calculated as $n=50$.

\subsection{Research Model}

After determining dependent and independent variables, multivariate regression is applied to analyze the data using SPSS application software.

The regression model used in this research is as follows:

$$
Y_{i}=\beta_{0}+\beta_{1} V A C A+\beta_{2} V A H U+\beta_{3} S T V A+\mu
$$

where, $\mathrm{Y}_{\mathrm{i}}$ is the dependent variable (the dependent variables are EPS and GR that has been tested using the above regression model), and independent variables are VACA, VAHC, and SCVA, which has been obtained from the information of the annual reports of the companies in the stock exchange for the period from 2005 to 2010 .

\subsubsection{Independent Variables}

Independent variable is the one measured or manipulated by the researcher to determine its impact on or its relation with other variables. In this research, there are three independent variables, which are the components of intellectual capital (based on the model of research): Physical (or Customer) Capital (CC), Human Capital (HC), and Structural Capital (SC). Value-added intellectual coefficient provides information on the efficiency of the value-added of tangible and intangible assets of the companies. Instead of evaluating the intellectual capital of the company, VAIC measures directly the efficiency of three types of assets of a company, which include:
1) Physical capital (CC)
2) Human capital (HC)
3) Structural capital (SC)

To calculate VAIC, the following method is applied:

\section{Calculation of value-added (VA):}

According to the beneficiaries of a company, the value-added is calculated using the following formula:

$$
V A=\text { output }- \text { input, }
$$

where, output is the resources obtained from the sales of goods and services, and input is the resources paid for the purchase of goods and services.

According to this approach, an individual or group affected by the transactions of a commercial enterprise is regarded as the beneficiary of that enterprise. This group of beneficiaries includes shareholders, personnel, financers, government, and society. Therefore, a criterion such as the valueadded of beneficiaries, used for the measurement of the performance of a commercial enterprise, is better than accounting profit, which only represents shareholder return. According to Belkaoui (2003), value-added is calculated using the following equation:

$R=S-C-D E-W-I-D D-T$,

where, $\mathrm{R}=$ changes in retained earning, $\mathrm{S}=$ net income or sales, $\mathrm{C}=$ cost price of the sold goods and services, $\mathrm{DE}=$ depreciation, $\mathrm{W}=$ wages and salaries of the personnel, $\mathrm{I}=$ interest costs, $\mathrm{DD}=$ distributed dividends, $\mathrm{T}=$ tax. 
The abovementioned equation can be reformulated as follows:

$S-C=D E+W+I+D D+T+R$.

This is called gross value-added approach. If the above equation is reformulated as follows, the new value-added approach is reached:

$S-C-D E=W+I+D D+T+R$.

The left-hand side of both equations calculates (net and gross) value-added, and the right-hand side of the equations represents the allocation of value-added among beneficiaries including personnel, financers, shareholders, and government. VA here means the net value created by the company within one year. As DD plus $\mathrm{R}$ is equal to the income or net profit after the deduction of tax, the above equation can be reformulated as follows:

$V A=S-C-D E=W+I+T+N I$

Where, NI is the net profit after the deduction of tax.

According to Pulik (2000) and Frier \& William (2003), the three main components of corporate resources are CA (applied physical capital), HU (human capital), and SC (structural capital), which are defined as follows:

$C A=$ Physical Capital + Financial Assets $=$ Intangible Assets + Total Assets,

$H U=$ Total Human Costs,

$S C=$ Created Value Added - Total Human Costs

The classification of corporate resources into CA and $\mathrm{HU}$ is based on corporate resource approach (Belkaoui, 2003). According to corporate resources approach, the resources of a company act like a drive for the performances of the company and competitive advantages. Such resources include tangible and intangible assets. $\mathrm{CA}$ is the indicator of tangible assets and $\mathrm{HU}$ the indicator of intangible assets.

\section{Calculation of VACA}

This coefficient represents the efficiency of financial and physical assets in the creation of valueadded for the company, and it is calculated as follows:

$V A C A=\frac{V A}{C A}$,

where, $\mathrm{CA}$ is the difference between total assets of a commercial enterprise, and total intangible assets of the same enterprise, and VA is the created value-added.

\section{Calculation of VAHC}

This coefficient represents the efficiency of human capital in the creation of value-added, and it is calculated as follows:

$V A H U=\frac{V A}{H U}$,

where, HU is the total human costs (including wages and salaries, as well as all other benefits payable to the personnel of a company), and VA is the created value-added.

\section{Calculation of SCVA}

This coefficient represents the efficiency of structural capital in the creation of value-added, and it is calculated as follows:

$S C V A=\frac{S C}{V A}$.

In this equation, $\mathrm{SC}$ is obtained as follows: 
$S C=V A-H U$,

where, VA represents value-added, and HU the total human costs

Calculation of VAIC

In conclusion, VAIC will be calculated by the summation of three value-added efficiency coefficients of customer (physical and financial) capital, human capital, and structural capital.

$V A I C=V A C A+V A H U+S C V A$.

\section{Dependent Variable}

Dependent variable is the one that is observed or measured to determine its impact in the independent variable. Dependent variable is forecasted by independent variable.

\section{Earning per Share (EPS)}

Earning per share is calculated by dividing the profit, allocated to the ordinary shareholders after the payment of the profit payable to the preferred shareholders, by the weighted average number of shares for the related fiscal year.

$$
E P S=\frac{\text { Profit to Shareholders }}{\text { Weighted Average Number of Shares }} \text {. }
$$

\section{Income Growth Ratio (GR)}

Income growth ratio is the difference between net profits of two fiscal years after the deduction of tax.

$G R=N I t 2-N I t 1$.

The income growth rate is obtained by dividing the difference between net profits of two fiscal periods, after the deduction of tax, by the net profit of the first fiscal year.

$$
G R=\frac{N I t 2-N I t 1}{N I t 1} \text {. }
$$

\subsection{The Results of Descriptive Statistics}

To study the general and basic characteristics of the variables required for the estimation of the model, their accurate analysis, and have a full knowledge of the statistical population studied in the research, it is required to study the variables by descriptive statistics.

The descriptive statistics of the variables studied in this research have been summarized in the Table 1. The summarized statistics consists of central indices including mean, median, as well as the indices of dispersion including variance, standard deviation, and skewness of the variables discussed in this research.

\section{Table 1}

The Results of Descriptive Statistics used in this Research

\begin{tabular}{ccccccc}
\hline Type of Variable & Variable & Average & Median & Variance & Standard Deviation & Skewness \\
\hline Dependent & EPS & 1038.25 & 738 & 1069850.9 & 1034.34 & 2.504 \\
& GR & 0.79 & 0.214 & 9.25 & 3.04 & 8.218 \\
\hline \multirow{3}{*}{ Independent } & VACA & 0.20 & 0.208 & 0.68 & 0.83 & -11.768 \\
& VAHC & 2.74 & 1.899 & 10.08 & 3.017 & 4.786 \\
& SCVA & 0.15 & 0.473 & 1.27 & 1.13 & -5.258 \\
\hline
\end{tabular}

where, EPS is earning per shares, GR income growth ratio, VACA value-added capital employed coefficient, VAHC value added human capital coefficient, and finally SCVA value-added structural capital efficiency coefficient. 


\subsubsection{Examining the Heteroscedasticity of Variance}

To study the heteroscedasticity of the variance of the error terms, both models are studied by ARCH Lagrange Multiplier (ARCH-LM) test and White test. The results of the variance heteroscedasticity determined based on ARCH-LM test are summarized in the following table:

The Test of the First Model (EPS)

ARCH-LM test for Heteroscedasticity

\section{Table 2}

The Results of ARCH-LM Test for the Heteroscedasticity of the First Model (EPS)

\begin{tabular}{lcc}
\hline Designation & Statistic Value & Probability \\
\hline F-statistic & 33.55083 & 0.000000 \\
Obs*R-squared & 29.77769 & 0.000000 \\
\hline
\end{tabular}

white Test for Heteroscedasticity

\section{Table 3}

The results of White Test for the Heteroscedasticity of the First Model (EPS)

\begin{tabular}{lll}
\hline Designation & Statistic Value & Probability \\
\hline F-statistic & 2.675505 & 0.015627 \\
Obs*R-squared & 15.49203 & 0.016756 \\
\hline
\end{tabular}

As the statistics of both tests are significant at the significance level of five percent, therefore, the homoscedasticity of variance is rejected and heteroscedasticity is confirmed.

This is proved based on the rejection of the assumption $\operatorname{Var}\left(U_{i}\right)=\delta^{2} I$. Such a problem in regression causes that the results of OLS may not be the most efficient. To solve this problem, generalized least square (GLS) method is used.

The Test of the Second Model (GR)

ARCH-LM test for Heteroscedasticity of the Second Model (GR)

\section{Table 4}

The results of ARCH-LM Test for the Heteroscedasticity of the Second Model (GR)

\begin{tabular}{lrr}
\hline \multicolumn{1}{c}{ Designation } & Statistic Value & Probability \\
\hline F-statistic & 0.019543 & 0.888935 \\
Obs*R-squared & 0.019700 & 0.888379 \\
\hline
\end{tabular}

White Test for Heteroscedasticity

Table 5

The Results of White Test for the Heteroscedasticity of the First Model (EPS)

\begin{tabular}{lcc}
\hline \multicolumn{1}{c}{ Designation } & Statistic Value & Probability \\
\hline F-statistic & 0.150172 & 0.988902 \\
Obs*R-squared & 0.923564 & 0.988345 \\
\hline
\end{tabular}

As the statistics of both tests are insignificant at the significance level of five percent, therefore, the homoscedasticity of variance is confirmed. Therefore, the method OLS can be applied.

\subsection{Research Hypotheses Tests}

To test the hypotheses of this research, the following equation has been applied:

$Y_{i}=\beta_{0}+\beta_{1} V A C A+\beta_{2} V A H U+\beta_{3} S T V A+\mu$. 
In this equation, $\mathrm{Y}_{\mathrm{i}}$ is the dependent variable (including EPS and GR that have been tested using this regression model), and the independent variables are SCVA, VAHC, and VACA.

\subsubsection{Regression Test of the First Hypothesis}

This test aims to study if there is any relation between intellectual capital and earning per share (EPS) of the companies listed on Tehran Stock Exchange.

$\mathrm{H}_{01}$ : there is no significant relation between intellectual capital and earning per share in the companies listed on the stock exchange.

$\mathrm{H}_{01}=\beta \mathrm{i}=0$

$\mathrm{H}_{11}=$ there is no significant relation between intellectual capital and earning per share in the companies listed on the stock exchange.

$\mathrm{H}_{01}=\beta \mathrm{i} \neq 0$

where, $\beta \mathrm{i}$ is the coefficients of the independent variables of this (pooled) multivariate regression.

To estimate the model based on the abovementioned methodology, pooled fixed-effects regression has been applied. T-Student test is used to test the significance of the coefficients of the independent variables, and F statistic is applied to study the simultaneous significance of the coefficients of all variables of the dependent variable.

\section{Table 6}

The Results of Pooled Regression

\begin{tabular}{|c|c|c|c|c|c|c|}
\hline Variable & Coefficient & $\begin{array}{c}\text { Standard } \\
\text { Deviation }\end{array}$ & T-Statistic & PROB & $\begin{array}{l}\text { Type of } \\
\text { Relation }\end{array}$ & $\begin{array}{c}\text { Significance } \\
\text { Level }\end{array}$ \\
\hline VACA & 50.38602 & 10.23050 & 4.925080 & $\% \ldots$ & $\begin{array}{l}\text { Positively } \\
\text { significant }\end{array}$ & $\% 99$ \\
\hline VAHC & 210.4173 & 12.20383 & 16.50596 & $\% \ldots$ & $\begin{array}{l}\text { Positively } \\
\text { significant }\end{array}$ & $\% 99$ \\
\hline \multirow[t]{2}{*}{ SCVA } & 43.80591 & 5.040263 & 8.691195 & $\% \ldots$ & $\begin{array}{l}\text { Positively } \\
\text { significant }\end{array}$ & $\% 99$ \\
\hline & (R-Sguared) & $\begin{array}{l}\text { (Adj-R- } \\
\text { Sguared) }\end{array}$ & $\begin{array}{l}\text { S.E.of } \\
\text { regression }\end{array}$ & F-Statistic & Prob. (F-Statistic) & D-W \\
\hline $\begin{array}{l}\text { (weighted } \\
\text { statistics) }\end{array}$ & 0.842446 & 0.800859 & $620 / 0241$ & $526 / 6843$ & $\% \ldots$ & 2.3259 \\
\hline $\begin{array}{l}\text { (un weighted } \\
\text { statistics) }\end{array}$ & 0.715645 & 0.640587 & 620.8764 & -- & -- & 2.029 \\
\hline
\end{tabular}

Here, EPS is earning per share, GR income growth ratio, VACA value-added capital employed coefficient, VAHC value-added human efficiency coefficient, and SCVA value-added structural capital.

As shown in the Table 6, the p-value of F statistic, (prob (F-statistic)), is equal to 0.0000 indicating that the whole regression is significant and it shows that the model is of significance at the confidence level of 99 percent. Therefore, the hypothesis $\mathrm{H}_{01}$ is rejected and $\mathrm{H}_{11}$ is confirmed.

At the next stage, the impact of each independent variable on the dependent variable EPS is studied. Significance value (prob.) of each variable shows that the independent variables VACA, VAHC, and SCVA are statistically valid, since the significance values of these three variables are smaller than the significance level of 0.05. Moreover, the value of the Durbin-Watson test is equal to 2.3259, which is an appropriate value. The determination coefficient (R2) equal to 0.8424446 indicates that almost 84 $\%$ of the changes of the dependent variable can be explained by the independent variables.

The final regression of this model is as follows:

$$
E P S_{i}=50.386 V A C A+201.427 V A H U+43.805 S T V A+\mu
$$




\subsubsection{Regression Test of the Second Hypothesis}

This test aims to study if there is any relation between intellectual capital and income growth (GR) of the companies listed on Tehran Stock Exchange.

$\mathrm{H}_{01}$ : there is no significant relation between intellectual capital and income growth (GR) in the companies listed on the stock exchange.

$\mathrm{H}_{02}=\beta \mathrm{i}=0$

$\mathrm{H}_{12}=$ there is no significant relation between intellectual capital and income growth (GR) in the companies listed on the stock exchange.

$\mathrm{H}_{01}=\beta \mathrm{i} \neq 0$

where, $\beta \mathrm{i}$ is the coefficients of the independent variables of the multivariate regression.

Table 7

The Results of Pooled Regression

\begin{tabular}{|c|c|c|c|c|c|c|}
\hline Variable & Coefficient & $\begin{array}{c}\text { Standard } \\
\text { Deviation }\end{array}$ & T-Statistic & PROB & Type of Relation & $\begin{array}{c}\text { Significance } \\
\text { Level }\end{array}$ \\
\hline VACA & 0.037497 & 0.002216 & 16.91961 & $\% \ldots$ & $\begin{array}{l}\text { Positively } \\
\text { significant }\end{array}$ & $99 \%$ \\
\hline VAHC & 0.101186 & 0.003964 & 25.52269 & $\% \ldots$ & $\begin{array}{l}\text { Positively } \\
\text { significant }\end{array}$ & $99 \%$ \\
\hline \multirow[t]{2}{*}{ SCVA } & 0.309935 & 0.023621 & 13.12112 & $\% \ldots$ & $\begin{array}{l}\text { Positively } \\
\text { significant }\end{array}$ & $99 \%$ \\
\hline & (R-Sguared) & $\begin{array}{l}\text { (Adj-R- } \\
\text { Sguared) }\end{array}$ & $\begin{array}{l}\text { S.E.of } \\
\text { regression }\end{array}$ & F-Statistic & $\begin{array}{c}\text { Prob. } \\
\text { (F-Statistic) }\end{array}$ & D-W \\
\hline $\begin{array}{l}\text { (weighted } \\
\text { statistics) }\end{array}$ & 0.416488 & 0.262465 & 3.026808 & 70.30544 & 0.0000 & 2.360565 \\
\hline $\begin{array}{l}\text { (unweighted } \\
\text { statistics) }\end{array}$ & 0.180091 & -0.036361 & 3.101402 & -- & -- & 2.841760 \\
\hline
\end{tabular}

Where, EPS is earning per share, GR income growth ratio, VACA value-added capital employed coefficient, VAHC value-added human efficiency coefficient, and SCVA value-added structural capital. As shown in the Table 7, the p-value of F statistic, (prob (F-statistic)), is equal to 0.0000 indicating that the whole regression is significant and it shows that the model is of significance at the confidence level of 99 percent. Therefore, the hypothesis $\mathrm{H}_{02}$ is rejected and $\mathrm{H}_{12}$ is confirmed.

At the next stage, the impact of each independent variable on the dependent variable GR is studied. Significance value (prob.) of each variable shows that the independent variables VACA, VAHC, and SCVA are statistically valid, since the significance values of these three variables are smaller than the significance level of 0.05. Moreover, the value of the Durbin-Watson test is equal to 2.360567, which is an appropriate value. The determination coefficient (R2) equal to 0.416488 indicates that almost 42 $\%$ of the changes of the dependent variable can be explained by the independent variables.

The final regression of this model is as follows:

$G R_{i}=0.037 V A C A+0.101 V A H U+0.309 S T V A+\mu$

\subsection{Analyses}

The last steps of the research are the most essential parts. The exact analysis of the collected data and proper conclusion, which are the basis for the future planning of the researched population, are of considerable importance. Indeed, the results must be based on actual documents so that the researched population accept the reliability and accuracy of such results and use them for its deficiencies by a comprehensive planning based on their forecast. In this section, a summation of the analyses from the past sections are provided, and then the results of this research are compared with those of the previous ones, and finally some recommendations are provided for future researches. 


\section{Findings}

In this section, the results of the abovementioned tests of the studied variables are provided:

- The result of variance heteroscedasticity (based on ARCH-LM and White tests) indicates that there is a heteroscedasticity in the first model stating that there is a relation between the components of intellectual capital and earning per share (EPS). To test the hypotheses, GLS method is to be applied.

- The result of autocorrelation of the variables shows that there is an autocorrelation between the components of intellectual capital and income growth (GR) of the variables. To solve this problem, GLS method is used for the test of hypotheses.

- Considering the results of the tests, it can be claimed that the components of intellectual capital (including human capital, customer capital, and structural capital) are in a positively significant relation with the earning per share of the companies for the period from 2005 to 2010 .

- Considering the results of the tests, it can be claimed that the components of intellectual capital (including human capital, customer capital, and structural capital) are related positively and significantly with the income growth of the companies for the period from 2005 to 2010 .

\subsection{Discussion}

According to the results of the present research and those of the previous studies, it can be claimed that the present results are consistent with the past ones from different aspects. This shows that the increase in the intellectual capital of the companies (including their human capital, customer capital, and structural capital) increases the income of the companies and as a result their profits and earning per share. Therefore, companies should pay special attentions to intellectual capital and take required measures to have a better performance, increase their efficiency, and such intangible assets. They should also try to assess such assets properly and encourage shareholders and investors for investment and increase in the performance of companies.

\section{Conclusion}

In the recent decade, special attentions have been paid to the measurement of intellectual capitals for reporting to the beneficiaries and finding a proper method for the evaluation of internal intangible assets and their intangible values in organizations. Indeed, intellectual capital provides a new and complete model for the extraction of actual value of organization, and it can be used to calculate performance and future value of company. Therefore, the following recommendations are provided based on the results of this research:

1- According to the results, companies are required to use this model for the preparation, provision, and analysis of actual and more complete financial statements in accounting systems of companies and their future decision-makings (for the purchase of the shares of other companies).

2- The use of this model for assessment by shareholders (investors) help them to have a correct and actual evaluation of the current and future value of the company (based on intellectual capital) for a better financial performance in the future.

3- It is also recommended that separate departments be established in companies for the assessment and measurement of the intellectual capital and better use of this intangible asset applied for a better financial performance.

4- The stock exchange should entail the companies listed on the stock exchange to report their annual intellectual capital for clarifying their information and the decisions made by shareholders and investors. 


\section{References}

Azad, N., \& Mohajeri, L. (2012). The effects of intellectual capital on financial performance: A case study of petrochemical and pharmaceutical firms. Management Science Letters, 2(2), 511-516.

Beattie, V., \& Thomson, S. J. (2007). Lifting the lid on the use of content analysis to investigate intellectual capital disclosures. Accounting Forum, 31, 129-163.

Bozbura, F. T., Beskese, A., \& Kahraman, C. (2007). Prioritization of human capital measurement indicators using fuzzy AHP. Expert Systems with Applications, 32, 1100-1112

Boekestein, B. (2009). Acquisitions reveal the intellectual capital of pharmaceutical companies. Journal of intellectual capital, 10(3), 389-400.

Chen, M.C., Cheng, S.J., Hwang, Y. (2005). An empirical investigation of the relationship between Intellectual capital and firm's market value and financial performance. Journal of Intellectual Capital, 6(2), 159-176.

Delgado-verde, M., de Castro, G.M., \& Navas- Lopez, J. E.(2011). organizational knowledge assets and innovation capability Evidence from Spanish manufacturing firms. Journal of intellectual capital, 12(1), 5-19.

Huggins, R. (2007). Intellectual assets and public policy. Journal of Intellectual, 8(4), 708-720.

Isaac, R. G., \& Herremans, I.M. (2009). Intellectual capital management :pathway to wealth creation. Journal of intellectual capital, 10(1), 81-92.

Manzari, M., Kazemi, M., Nazemi, S., \& Pooya, A. (2012). Intellectual capital: Concepts, components and indicators: A literature review. Management Science Letters, 2(7), 2255-2270.

Mouritsen, J., Larsen, H.T., \& Bukh, P.N.D. (2001). Intellectual capital and the 'capable firm': narrating, visualising and numbering for managing knowledge. Accounting, Organizations and Society, 26, 735-762.

Wall, A., Kirk, R., \& Martin, G. (2004). Intellectual Capital: Measuring the Immeasurable? CIMA Publishing, Oxford.

Yang, C. C., \& Lin, C. Y. Y. (2009). Does intellectual capital mediate the relationship between HRM and organizational performance? Perspective of a healthcare industry in Taiwan. The International Journal of Human Resource Management, 20(9), 1965-1984. 